\title{
Comunicación entre el IMLK - UPOLI y El Vaticano
}

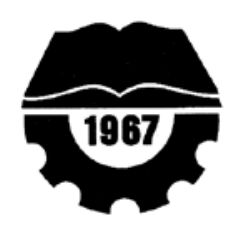

Managua, 30 de julio de 2013

\author{
Su Santidad Papa Francisco \\ Obispo de Roma \\ EI Vaticano \\ Su Despacho
}

Su Santidad:

Tenemos el altísimo honor y privilegio de remitirle el número 60 de nuestra Revista "Cultura de Paz", la cual editamos de manera ininterrumpida desde hace 19 años. Nuestro Instituto, fundado exactamente hace 20 años, la ha asumido como uno de los instrumentos más importantes de su quehacer para diseminar en nuestra región y el mundo, la Cultura de la Paz. Paradigma que sabemos, también lo comparte la iglesia universal, pues promover la paz fruto de la justicia, es un mandato del evangelio.

Estamos muy contentos y esperanzados con los mensajes y actitudes con los cuales Usted ha inaugurado su gestión al frente de la iglesia católica, pues señala el camino de Jesús, Aquel en quien Dios, en su libre Gracia, asumió el misterio de la encarnación, haciéndose hombre y que siendo Rico se hizo pobre, siendo Señor se hizo servidor, siendo Creador se hizo criatura, siendo Santo se hizo pecado, siendo la Vida misma asumió la muerte, siendo Todo se hizo nada por nuestra salvación y la del todo el universo.

Me permito comentarle que nuestro Instituto fue quien promovió que la Asamblea General de las Naciones Unidas declarara el año 2009, Año Internacional de la Reconciliación, iniciativa que contó desde su gestación (1999), con el respaldo incondicional de El Vaticano.

El Padre Leonardo Boff, tuvo a bien dispensarnos la oportunidad de realizarle una entrevista sobre varios temas de especial importancia y actualidad, es por ello que tenemos también la satisfacción de enviársela, para que Usted personalmente la lea. Las reflexiones sobre su personalidad, los desafíos actuales para la iglesia y los signos que usted representa, auguran que con el acompañamiento del Dios del Amor y la Vida y de todos los hombres y mujeres de buena voluntad que le acompañamos, sabrá inaugurar la iglesia del tercer milenio.

Esperando que esta carta llegue a sus manos, tenga la confianza del acompañamiento y oraciones de nuestro pueblo.

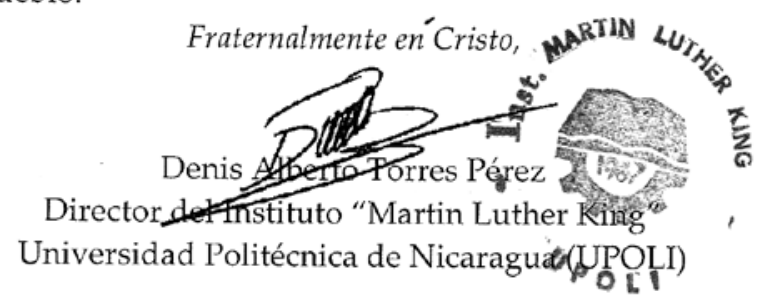

Cc: Señor Fortunatus Nwachukwu, Nuncio Apostólico en Nicaragua

Archivo.

\section{UPOLI SIRVIENDO A LA COMUNIDAD \\ UNIVERSIDAD POLITÉCNICA DE NICARAGUA. Tel.: 2289-7740 / 44 Fax: 2249-9232 \\ Correo Electrónico: rectoria@upoli.edu.ni \\ Ap. Postal 3595, Managua, Nicaragua. \\ Fundada por la Convención Bautista de Nicaragua.}




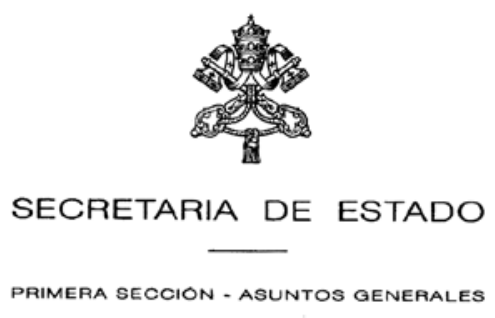

Vaticano, 30 de agosto de 2013

\section{N. 18.232}

Estimado en el Señor:

A través de los buenos oficios de la Nunciatura Apostólica en Nicaragua, y movido por sentimientos de filial afecto, ha tenido a bien enviar al Santo Padre una atenta carta, acompañada de una publicación.

El Papa Francisco agradece tan deferente gesto, al cual corresponde formulando los mejores votos, a la vez que implora abundantes dones divinos de paz y misericordia.

Aprovecho gustoso la oportunidad para manifestarle los sentimientos de mi distinguida consideración.

\section{Peto B. Well}

Mons. Peter B. Wells

Asesor

\section{Denis Alberto TORRES PÉREZ}

